\title{
Delayed Release Particle Tablet Dosage
} Form

National Cancer Institute

\section{Source}

National Cancer Institute. Delayed Release Particle Tablet Dosage Form. NCI Thesaurus.

Code C42997.

A tablet composed of individual fragments have been coated with a substance that is designed to impede the immediate release of the active and/or inert ing redient(s) after administration. 